\title{
EFEKTIVITAS SISTEM INFORMASI AKUNTANSI (SIA) PADA LEMBAGA PERKREDITAN DESA DI KECAMATAN TEJAKULA
}

\author{
Made Pusata ${ }^{1}$, Made Ary Meitriana ${ }^{2}$, I Nyoman Sujana ${ }^{3}$ \\ Jurusan Pendidikan Ekonomi \\ Universitas Pendidikan Ganesha \\ Singaraja, Indonesia
}

\begin{abstract}
e-mail: pusatamade93@gmail.com ${ }^{1}$, ary.meitriana@yahoo.co.id, ${ }^{2}$ sujanatbn@gmail.com ${ }^{3}$
\end{abstract}

\begin{abstract}
Abstrak
Penelitian ini bertujuan untuk mengetahui efektivitas sistem informasi akuntansi pada Lembaga Perkreditan Desa di Kecamatan Tejakula. Jenis penelitian ini merupakan penelitian deskriptif. Data dikumpulkan dengan metode kuesioner. Sampel penelitian ini adalah karyawan Lembaga Perkreditan Desa di Kecamatan Tejakula yang berjumlah 64 orang. Teknik analisis data menggunakan analisis deskriptif untuk menentukan efektivitas sistem informasi akuntansi. Hasil penelitian menunjukkan bahwa efektivitas sistem informasi akuntansi pada Lembaga Perkreditan Desa di Kecamatan Tejakula berada pada kriteria efektif. Hal ini dapat dilihat dari perolehan masing-masing aspek, yaitu aspek kinerja memiliki kriteria efektif sebesar 982, aspek informasi memiliki kriteria efektif sebesar 728, aspek ekonomis memiliki kriteria efektif sebesar 505, aspek kontrol memiliki kriteria efektif sebesar 759, aspek efisiensi memiliki kriteria efektif sebesar 995, dan aspek pelayanan memiliki kriteria sangat efektif sebesar 743 .
\end{abstract}

Kata kunci: efektivitas, sistem informasi akuntansi.

\begin{abstract}
This research was aimed to identify the effectiveness of accounting information systems at Village Credit Institution in Tejakula District. This type of research was descriptive research. Data were collected by questionnaire method. The sample of this research were employees of Village Credit Institution in Tejakula District amounted to 64 people. Data analysis techniques use descriptive analysis to determine the effectiveness of accounting information systems. The result of this research shows that the effectiveness of accounting information system at Village Credit Institution in Tejakula District was in effective criteria. This can be seen from the result of each aspect, that aspect of performance has effective criteria of 982, information aspect has effective criterion of 728 , economic aspect has effective criterion of 505 , control aspect has effective criterion of 759 , efficiency aspect has an effective criterion of 995 , and the service aspect has a very effective criterion of 743 .
\end{abstract}

Keywords: effectiveness, accounting information systems.

\section{PENDAHULUAN}

Sistem Informasi Akuntansi (SIA) mempunyai fungsi yang penting didalam bidang akuntansi, karena akuntansi mendukung dan membantu manajemen dalam penyediaan informasi. Kemampuan manajer untuk mengalokasikan sumber daya secara efisien dan efektif memerlukan informasi akuntansi sebagai salah satu dasar penting dalam pengambilan keputusan alokasi dan laporan keuangan perusahaan, untuk menghasilkan informasi akuntansi yang dibutuhkan sistem informasi akuntansi (Santi, 2014). Sistem Informasi 
Akuntansi (SIA) dapat dimanfaatkan oleh banyak pihak untuk mencapai keunggulan perusahaan melalui kecepatan, fleksibilitas, integrasi, dan keakuratan informasi yang dihasilkan. SIA mampu memberikan kesempatan bagi pebisnis untuk meningkatkan efisiensi dan efektivitas dalam pengambilan keputusan sehingga memungkinkan perusahaan mencapai keunggulan kompetitif

Menurut Bodnar \& William (2006), SIA merupakan kumpulan sumber daya seperti manusia dan peralatan yang dirancang untuk mengubah data keuangan dan data lainnya ke dalam informasi. Salah satu komponen dari SIA yaitu teknologi. Hadirnya teknologi, dapat membantu manajer perusahaan dalam kegiatan organisasi bisnis. Menurut Mulyadi (2008), "teknologi ibarat mesin untuk menjalan sistem informasi." Teknologi menangkap masukan, menjalankan model, menyimpan dan mengakses data, menghasilkan dan menyampaikan keluaran serta mengendalikan seluruh sistem.

Pada mulanya sistem informasi perusahaan dikerjakan sepenuhnya oleh manusia, kemudian sejalan dengan perkembangan teknologi, sistem informasi manual yang dikerjakan sepenuhnya oleh manusia mulai ditransformasikan ke dalam sistem berbasis komputer. Komputer tidak hanya dapat melakukan perhitunganperhitungan dengan cepat, tetapi juga merupakan prosesor yang sangat akurat dan ekspansif. Jika dibandingkan dengan manusia, manusia sangat lamban, dan terbatas. Komputer dapat memproses ratusan transaksi dalam suatu waktu tertentu sementara manusia hanya biasa memproses satu transaksi. Hal ini terjadi karena kemampuan komputer untuk mengolah data yang jauh melebihi kecepatan manusia. Selain mempengaruhi pemerosesan dan penyimpanan data, komputer juga mempunyai dampak siginifikan terhadap pengorganisasian perusahaan, pengambilan keputusan dan pendayagunaan fungsi akuntansi.

$$
\text { Pekerjaan akuntan dalam }
$$

menghasilkan informasi keuangan dan informasi non keuangan saat ini relative mudah dilakukan. Hal tersebut harus di dukung akan adanya kinerja yang baik dari karyawan. Menurut Moeheriono (2010), kinerja adalah hasil kerja yang dapat dicapai oleh seseorang atau sekelompok orang dalam suatu organisasi baik secara kuantitatif maupun kualitatif, sesuai dengan kewenangan dan tugas tanggung jawab masing-masing, dalam upaya mencapai tujuan organisasi bersangkutan secara legal, tidak melanggar hukum dan sesuai dengan moral dan etika. Kinerja individu dapat dilihat dari hasil kerja yang dicapai individu tersebut dalam melaksanakan tugas-tugas yang dibebankan kepadanya atas dasar kecakapan, pengalaman, serta keterampilan yang digunakan oleh individu dalam menyelesaikan suatu pekerjaan. Pencapaian kinerja juga berkaitan dengan kesesuaian antara sistem informasi yang diterapkan dengan tugas, kebutuhan dan kemampuan individu dalam organisasi tersebut. Tugas, kebutuhan dan kemampuan individu hendaknya dipertimbangkan dalam menerapkan suatu sistem informasi dalam organisasi. Goodhue \& Thompson (dalam Jumaili, 2005) menemukan kecocokan tugas teknologi akan mengarahkan individu untuk mencapai kinerja yang lebih baik. Menurut Bastian (2005:336), efektivitas adalah, Hubungan antara output dan tujuan dimana efektivitas diukur berdasarkan seberapa jauh tingkat output atau keluaran, kebijakan dan prosedur dari organisasi untuk mencapai tujuan yang telah ditetapkan. Efektivitas merupakan kemampuan untuk memilih tujuan yang tepat atau peralatan yang tepat untuk mencapai tujuan yang telah ditetapkan, menyangkut bagaimana melakukan pekerjaan yang benar.

Bank adalah badan usaha yang menghimpun dana dari masyarakat dalam bentuk simpanan dan menyalurkannya kembali kepada masyarakat dalam bentuk kredit maupun bentuk lain dalam rangka meningkatkan taraf hidup rakyat banyak" (Kasmir, 2004:23). Terdapat banyak jenis lembaga keuangan yang ada di Indonesia salah satunya adalah Lembaga Perkreditan Desa. Berdasarkan Peraturan Daerah Provinsi Tingkat I Bali No. 8 Tahun 2002 pasal 2, disebutkan bahwa Lembaga Perkreditan Desa adalah badan usaha milik Desa yang melaksanakan kegiatan usaha di lingkungan desa dan krama desa. Tujuan 
didirikannya sebuah LPD pada setiap desa adat, berdasarkan penjelasan dari Peraturan Daerah No.2/1988 dan No. 8 tahun 2002 mengenai LPD

Kinerja individual mengacu pada standar kerja yang telah ditetapkan oleh organisasi sebelumnya. Rahmawati (2008) menjelaskan bahwa kesesuaian tugas berhubungan dengan sejauh mana kemampuan individual menggunakan teknologi informasi dalam melaksanakan tugas untuk meningkatkan kinerja individual. Kepercayaan terhadap teknologi sistem informasi dalam mengevaluasi kinerja individu diperlukan oleh manajemen untuk memastikan bahwa teknologi sistem informasi berbasis komputer yang digunakan dapat dipakai untuk mengendalikan kinerja bawahan. Kepercayaan adalah hal yang diperlukan oleh pemakai teknologi sistem informasi agar pemakai tersebut merasa bahwa teknologi sistem informasi yang diterapkan dapat meningkatkan kinerja individual dalam menjalankan kegiatan dalam perusahaan. Sari (2009) berpendapat bahwa pemakaian SIA dalam suatu perusahaan dilihat dari seorang pengguna komputer meningkatkan kemampuannya dalam menggunakan komputer, dengan demikian semakin mahir pemakai maka akan semakin efektif penerapan SIA di suatu perusahaan yang akan mengakibatkan meningkatnya kinerja individual yang bersangkutan.

Berdasarkan observasi awal yang peneliti lakukan pada karyawan Lembaga Perkreditan Desa (LPD) di Kecamatan Tejakula. Pada zaman teknologi sekarang ini sudah banyak LPD yang beralih dari sistem manual ke sistem berbasis komputer dan telah menerapkan SIA dalam mengolah datanya. Saat ini LPD di Kecamatan Tejakula sudah menerapkan SIA karena berfungsi sebagai back-up dan perbandingan laporan keuangan yang secara manual. Selama menerapkan SIA berbasis komputer LPD di Kecamatan Tejakula belum mengetahui tingkatan efektivitas dari penerapannya sehingga LPD tidak mengetahui SIA sudah efektif atau belum dengan program excel. Padahal dengan mengetahui tingkat efektivitas penerapan SIA berbasis komputer maka
LPD dapat mengukur keberhasilan dari SIA berbasis komputer yang diterapkan sudah sesuai dengan harapan. Hal ini yang melatarbelakangi diadakannya penelitian mengenai. Efektivitas Sistem Informasi Akuntansi (SIA) pada Lembaga Perkreditan Desa Di Kecamatan Tejakula. Penelitian ini bertujuan untuk mengetahui efektivitas SIA kinerja individual pada lembaga Perkreditan Desa di Kecamatan Tejakula.

\section{METODE}

Jenis penelitian yang digunakan dalam penelitian ini adalah penelitian deskriptif. Penelitian desktiptif adalah penelitian yang bertujuan untuk memberikan atau menjabarkan suatu keadaan atau fenomena yang terjadi saat ini dengan menggunakan prosedur ilmiah untuk menjawab masalah secara aktual (Sugiyono, 2011). Penelitian deskriptif dilakukan untuk memperoleh informasi mengenai efektivitas sistem informasi akuntansi (SIA) pada Lembaga Perkreditan Desa di Kecamatan Tejakula.

Penelitian ini dilakukan pada Lembaga Perkreditan Desa di Kecamatan Tejakula. Dalam penelitian ini yang menjadi subjek penelitian adalah karyawan LPD di Kecamatan Tejakula yang berjumlah 64 orang. Objek penelitian adalah variabel efektivitas SIA pada LPD di Kecamatan Tejakula.

Jenis data dalam penelitian ini adalah data kuantitatif berupa angka-angka jawaban dari responden mengenai kuesioner efektivitas SIA pada LPD di Kecamatan Tejakula. Sumber data primer dalam penelitian ini berupa data efektivitas SIA yang bersumber dari jawaban kuesioner yang dijawab langsung oleh karyawan terkait dengan efektivitas SIA. Dalam penelitian ini yang termasuk ke dalam data sekunder berupa data dokumen nama karyawan LPD di Kecamatan Tejakula.

Adapun metode pengumpulan data yang digunakan dalam penelitian ini adalah metode dokumentasi dan kuesioner. Metode dokumentasi dipergunakan untuk mengumpulkan atau memperoleh data berupa nama dan jumlah karyawan LPD di Kecamatan Tejakula. Kuesioner adalah teknik pengumpulan data yang dialakukan 
dengan cara memberikan seperangkat pertanyaan atau peryataan tertulis kepada responden untuk dijawabnya (Sugiyono, 2013). Kuesioner digunakan untuk mendapatkan data tentang efektivitas SIA

Instrumen penelitian merupakan alat yang digunakan untuk mengukur variabel dalam rangka mengumpulkan data. Instrumen penelitian yang digunakan adalah kuesioner. Data yang telah dikumpulkan digunakan sistem skor, dimana jawaban pertanyaan diberi skor dengan menggunakan skala likert. Adapun kategori penskoran kuesioner efektivitas SIA dengan skala likert. Skala likert digunakan untuk mengkur sikap, pendapat, dan persepsi seseorang atau sekelompok orang tentang fenomena sosial (Sugiyono, 2013). Dalam skala ini, responden menyatakan persetujuannya dan ketidaksetujuannya terhadap sejumlah pernyataan yang berhubungan dengan obyek yang diteliti. Jawaban dari setiap item instrumen yang menggunakan skala likert mempunyai gradasi dari sangat positif sampai sangat negatif (Sugiyono, 2013). Pengukuran variabel menggunakan skala likert dengan lima alternatif jawaban masing-masing diberi skor, yaitu skor lima = sangat setuju (SS), skor empat = setuju (S), skor tiga = kurang setuju (KS), skor dua $=$ tidak setuju (TS), dan skor satu = sangat tidak setuju (STS). Skor tersebut masih berupa data ordinal, sehingga terlebih dahulu harus ditransformasikan menjadi data interval dengan bantuan MSI (Method of Successive Interval).

Kuesioner sebagai instrumen pengumpulan data ordinal yang merupakan penjabaran dari indikator variabel sebelum digunakan untuk mengumpulkan data di lapangan terlebih dahulu harus diuji tingkat validitas dan reliabilitasnya. Untuk menguji tingkat validitas dan reliabilitas instrument penelitian akan diujikan kepada tiga puluh responden.

Teknik analisis data yang digunakan dalam penelitian ini adalah analisis deskriptif. Analisis deskriptif adalah data yang berbentuk kata, kalimat, skema dan gambar dianalisis dengan cara mengelompokkan data, memberikan gambaran dan menggunakan teori untuk kemudian ditarik suatu kesimpulan
(Sugiyono, 2005). Untuk menentukan persentase efektivitas sistem informasi akuntansi sebagai pengolah data dilakukan sebagai berikut.

Pertama menentukan skor tertinggi dan skor terendah yang mungkin dicapai dari kuesioner yang diajukan, skor tertinggi ideal $=\mathrm{a}$, skor terendah ideal = b. Kedua menentukan besarnya range skor berdasarkan seluruh total skor tertinggi yang mungkin dicapai dengan total skor terendah yang mungkin dicapai. Formulasi range skor adalah sebagai berikut (Sugiyono, 2005).

Range skor $=\mathrm{a}-\mathrm{b}$

Ketiga menentukan besarnya interval skor berdasarkan perbandingan antara range skor nilai dengan jumlah kriteria nilai yang diperlukan. Terdapat lima kriteria sebagai berikut (Sukardi, 2003). Pertama kriteria sangat efektif (KSE). Kedua kriteria efektif (KE). Ketiga kriteria Cukup Efektif (KCE). Keempat kriteria kurang efektif (KKE). Kelima kriteria tidak efektif (KTE)

Formulasi interval skor adalah sebagai berikut (Supranto, 2001).

$$
c=\frac{a-b}{k}
$$

dimana $\mathrm{k}=$ jumlah kelas interval

Keempat menentukan besarnya interval skor berdasarkan perbandingan antara range skor dengan jumlah kriteria skor yang diperlukan sebagai berikut (Sukardi, 2003). Pertama $b+4 c \leq K S E \leq a$, kedua $b+3 c \leq$ $K E<b+4 c$, ketiga $b+2 c \leq K C E<b+3 c$, keempat $b+c \leq K K E<b+2 c$, kelima $b \leq$ $\mathrm{KTE}<\mathrm{b}+\mathrm{c}$

Kriteria efektivitas SIA pada Lembaga Perkreditan Desa di Kecamatan Tejakula dinilai dari indikator: Pertama sistem menyediakan data yang cukup, kedua sistem menyediakan waktu respon yang cukup, ketiga sistem menyediakan informasi tepat waktu, saling terkait, dan akurat, keempat sistem menawarkan kontrol yang memadai untuk mengatasi penipuan dan penggelapan, kelima sistem harus memberdayakan sumber daya yang tersedia termasuk orang, waktu, aliran form, keenam sistem dapat meminimalkan penundaan proses, dan ketujuh sistem menyediakan layanan yang diinginkan dan 
andal, dapat tentukan dengan perhitungan sebagai berikut.

Pertama a $=5 \times 2 \times 64=640$

Kedua $b=1 \times 2 \times 64=128$

Ketiga Range skor $=a-b=640-128=$ 512

Keempat $\mathrm{c}=\frac{\mathrm{a}-\mathrm{b}}{5} .=\frac{512}{5}=102$

Berdasarkan perhitungan yang telah dipaparkan, maka rentang skor untuk aspek ekonomis dapat ditentukan dengan formulasi berikut.

Pertama kriteria sangat efektif (KSE): $538 \leq$ KSE $\leq 640$

Kedua kriteria efektif (KE): $435 \leq \mathrm{KE}<538$

Ketiga kriteria Cukup Efektif (KCE): $333 \leq$ KCE $<435$

Keempat kriteria kurang efektif (KKE): 230 $\leq \mathrm{KKE}<333$

Kelima kriteria tidak efektif (KTE): $128 \leq$ KTE $<230$

Kriteria efektivitas SIA pada Lembaga

Perkreditan Desa di Kecamatan Tejakula dinilai dari indikator. Pertama sistem menyediakan informasi yang berguna bagi pengguna dan manajer, kedua sistem menawarkan tingkat dan kapasitas pelayanan yang memadai, ketiga sistem mengurangi biaya atau meningkatkan keuntungan bisnis, keempat sistem menjamin keakuratan dan keamanan data dan informasi, dan kelima sistem bersifat fleksibel dan dapat dikembangkan, dapat tentukan dengan perhitungan sebagai berikut.

Pertama $a=5 \times 1 \times 64=320$

Kedua $b=1 \times 1 \times 64=64$

Ketiga range skor $=a-b=320-64=256$

Keempat $\mathrm{c}=\frac{\mathrm{a}-\mathrm{b}}{5} .=\frac{256}{5}=51,2$

Berdasarkan perhitungan yang telah dipaparkan, maka rentang skor untuk aspek ekonomis dapat ditentukan dengan formulasi berikut.

Pertama kriteria sangat efektif (KSE): 268,8 $\leq \mathrm{KSE} \leq 320$

Kedua kriteria efektif (KE): $217,6 \leq \mathrm{KE}<$ 268,8

Ketiga kriteria cukup efektif (KCE): 166,4 $\leq$ $\mathrm{KCE}<217,6$

Keempat kriteria kurang efektif (KKE): $115,2 \leq \mathrm{KKE}<166,4$
Kelima kriteria tidak efektif (KTE): $64 \leq$ KTE $<115,2$

Kriteria efektivitas SIA pada Lembaga Perkreditan Desa di Kecamatan Tejakula dinilai dari aspek kinerja dan efisiensi dapat tentukan dengan perhitungan sebagai berikut.

Pertama a $=5 \times 4 \times 64=1280$

Kedua $b=1 \times 4 \times 64=256$

Ketiga range skor $=a-b=1280-256=$ 1024

Keempat $\mathrm{c}=\frac{\mathrm{a}-\mathrm{b}}{5}=\frac{1024}{5}=205$

Berdasarkan perhitungan yang telah dipaparkan, maka rentang skor untuk aspek kinerja dan efisiensi dapat ditentukan dengan formulasi berikut.

Pertama kriteria sangat efektif (KSE): 1075 $\leq \mathrm{KSE} \leq 1280$

Kedua kriteria efektif (KE): $870 \leq \mathrm{KE}<1075$

Ketiga kriteria Cukup Efektif (KCE): $666 \leq$ KCE $<870$

Keempat kriteria kurang efektif (KKE): 461 $\leq \mathrm{KKE}<666$

Kelima kriteria tidak efektif (KTE): $256 \leq$ $\mathrm{KTE}<461$

Kriteria efektivitas SIA pada Lembaga Perkreditan Desa di Kecamatan Tejakula dinilai dari aspek informasi, kontrol, dan pelayanan dapat tentukan dengan perhitungan sebagai berikut.

Pertama a $=5 \times 3 \times 64=960$

Kedua $b=1 \times 3 \times 64=192$

Ketiga range skor $=a-b=960-192=$ 768

Keempat $\mathrm{c}=\frac{\mathrm{a}-\mathrm{b}}{5} .=\frac{768}{5}=154$

Berdasarkan perhitungan yang telah dipaparkan, maka rentang skor untuk aspek informasi, kontrol, dan pelayanan dapat ditentukan dengan formulasi berikut.

Pertama kriteria sangat efektif (KSE): $806 \leq$ KSE $\leq 960$

Kedua kriteria efektif (KE): $653 \leq \mathrm{KE}<806$

Ketiga kriteria cukup efektif (KCE): $499 \leq$ $\mathrm{KCE}<653$

Keempat kriteria kurang efektif (KKE): 346 $\leq \mathrm{KKE}<499$

Kelima kriteria tidak efektif (KTE): $192 \leq$ $\mathrm{KTE}<346$

Kriteria efektivitas SIA pada Lembaga Perkreditan Desa di Kecamatan Tejakula dinilai dari aspek ekonomis dapat tentukan 
dengan perhitungan sebagai berikut.

Pertama $a=5 \times 2 \times 64=640$

Kedua $b=1 \times 2 \times 64=128$

Ketiga range skor $=a-b=640-128=$ 512

Keempat $\mathrm{c}=\frac{\mathrm{a}-\mathrm{b}}{5} .=\frac{512}{5}=102$

Berdasarkan perhitungan yang telah dipaparkan, maka rentang skor untuk aspek ekonomis dapat ditentukan dengan formulasi berikut.

Pertama kriteria sangat efektif (KSE): $538 \leq$ KSE $\leq 640$

Kedua kriteria efektif (KE): $435 \leq \mathrm{KE}<538$
Ketiga kriteria cukup efektif (KCE): $333 \leq$ KCE $<435$

Keempat kriteria kurang efektif (KKE): 230 $\leq \mathrm{KKE}<333$

Kelima kriteria tidak efektif (KTE): $128 \leq$ $\mathrm{KTE}<230$

\section{HASIL DAN PEMBAHASAN}

Hasil efektivitas sistem informasi akuntansi (SIA) pada Lembaga Perkreditan Desa di Kecamatan Tejakula dapat ditinjau dari aspek kinerja, informasi, ekonomis, kontrol, efisiensi, dan pelayanan. Dapat ditunjukkan pada tabel 1 sebagai berikut.

Tabel 1. Efektivitas Sistem Informasi Akuntansi (SIA) pada Aspek Kinerja

\begin{tabular}{|c|c|c|}
\hline Indikator & Skor & $\begin{array}{c}\text { Kriteria } \\
\text { Efektivitas }\end{array}$ \\
\hline Sistem menyediakan data yang cukup & 489 & $\begin{array}{c}435 \leq \mathrm{KE}< \\
538\end{array}$ \\
\hline $\begin{array}{l}\text { Sistem menyediakan waktu respon yang } \\
\text { cukup }\end{array}$ & 493 & $\begin{array}{c}435 \leq \mathrm{KE}< \\
538\end{array}$ \\
\hline Total Skor Aspek Kinerja & 982 & $\begin{array}{c}870 \leq \mathrm{KE}< \\
1075\end{array}$ \\
\hline $\begin{array}{l}\text { Sesuai dengan tabel } 1 \text { dapat } \\
\text { disimpulkan bahwa efektivitas SIA pada } \\
\text { aspek kinerja memiliki total skor sebesar } \\
\text { 982. Jika dibandingkan dengan kriteria } \\
\text { efektivitas, maka efektivitas SIA pada } \\
\text { Lembaga Perkreditan Desa di Kecamatan } \\
\text { Tejakula pada aspek kinerja masuk dalam }\end{array}$ & & $\begin{array}{l}\text { range skor } 870 \leq \mathrm{KE}<1075 \text { dengan } \\
\text { Kriteria Efektif (KE). } \\
\text { Efektivitas SIA pada Lembaga } \\
\text { Perkreditan Desa di Kecamatan Tejakula } \\
\text { dinilai dari aspek informasi dapat } \\
\text { ditunjukkan seperti pada tabel } 2 \text { sebagai } \\
\text { berikut. }\end{array}$ \\
\hline
\end{tabular}

Tabel 2. Efektivitas Sistem Informasi Akuntansi (SIA) pada Aspek Informasi

\begin{tabular}{|c|c|c|}
\hline Indikator & Skor & $\begin{array}{l}\text { Kriteria } \\
\text { Efektivitas }\end{array}$ \\
\hline $\begin{array}{l}\text { Sistem menyediakan informasi tepat } \\
\text { waktu, saling terkait, dan akurat }\end{array}$ & 491 & $435 \leq \mathrm{KE}<538$ \\
\hline $\begin{array}{l}\text { Sistem menyediakan informasi yang } \\
\text { berguna bagi pengguna dan manajer }\end{array}$ & 237 & $\begin{array}{c}217,6 \leq \mathrm{KE}< \\
268,8\end{array}$ \\
\hline $\begin{array}{c}\text { Total Skor } \\
\text { Aspek Informasi }\end{array}$ & 728 & $653 \leq \mathrm{KE}<806$ \\
\hline $\begin{array}{l}\text { Sesuai dengan tabel } 2 \text { dapa } \\
\text { disimpulkan bahwa efektivitas SIA pada } \\
\text { aspek informasi memiliki total skor sebesar } \\
\text { 728. Jika dibandingkan dengan kriteria } \\
\text { efektivitas, maka efektivitas SIA pada } \\
\text { Lembaga Perkreditan Desa di Kecamatan }\end{array}$ & & $\begin{array}{l}\text { dalam range skor } 653 \leq \mathrm{KE}<806 \text { dengan } \\
\text { Kriteria Efektif (KE). } \\
\quad \text { Efektivitas SIA pada Lembaga } \\
\text { Perkreditan Desa di Kecamatan Tejakula } \\
\text { dinilai dari aspek ekonomis dapat } \\
\text { ditunjukkan seperti pada tabel } 3 \text {. }\end{array}$ \\
\hline
\end{tabular}


Tabel 3. Efektivitas Sistem Informasi Akuntansi (SIA) pada Aspek Ekonomis

\begin{tabular}{|c|c|c|c|}
\hline Indikator & Skor & Range Skor & $\begin{array}{l}\text { Kriteria } \\
\text { Efektivitas }\end{array}$ \\
\hline $\begin{array}{llc}\text { Sistem menawarkan tingkat } & \text { dan } \\
\text { kapasitas pelayanan yang memadai } & \end{array}$ & 256 & $217,6 \leq \mathrm{KE}<268,8$ & Kriteria Efektif \\
\hline $\begin{array}{l}\text { Sistem mengurangi biaya atau } \\
\text { meningkatkan keuntungan bisnis }\end{array}$ & 249 & 217,6 & Kriteria Efektif \\
\hline Total Skor A & 505 & $435 \leq \mathrm{KE}<538$ & Kriteria Efektif \\
\hline $\begin{array}{l}\text { Sesuai dengan tabel } 3 \text { dapat } \\
\text { disimpulkan bahwa efektivitas SIA pada } \\
\text { aspek ekonomis memiliki total skor sebesar } \\
505 \text {. Jika dibandingkan dengan kriteria } \\
\text { efektivitas, maka efektivitas sistem SIA } \\
\text { pada Lembaga Perkreditan Desa di } \\
\text { Kecamatan Tejakula pada aspek ekonomis }\end{array}$ & & \multicolumn{2}{|c|}{$\begin{array}{l}\text { masuk dalam range skor } 435 \leq \mathrm{KE}<538 \\
\text { dengan Kriteria Efektif (KE). } \\
\text { Efektivitas sistem informasi akuntansi } \\
\text { (SIA) pada Lembaga Perkreditan Desa di } \\
\text { Kecamatan Tejakula dinilai dari aspek } \\
\text { kontrol dapat ditunjukkan seperti pada tabel } \\
\text { 4. }\end{array}$} \\
\hline
\end{tabular}

Tabel 4. Efektivitas Sistem Informasi Akuntansi (SIA) pada Aspek Kontrol

\begin{tabular}{|c|c|c|c|}
\hline Indikator & Skor & Range Skor & $\begin{array}{c}\text { Kriteria } \\
\text { Efektivitas }\end{array}$ \\
\hline $\begin{array}{l}\text { Sistem menawarkan kontrol yang } \\
\text { memadai untuk mengatasi penipuan dan } \\
\text { penggelapan }\end{array}$ & 508 & $435 \leq \mathrm{KE}<538$ & Kriteria Efektif \\
\hline $\begin{array}{l}\text { Sistem menjamin keakuratan dan } \\
\text { keamanan data dan informasi }\end{array}$ & 251 & 217,6 & Kriteria Efektif \\
\hline Total Skor Aspek Kontrol & 759 & $653 \leq \mathrm{KE}<806$ & Kriteria Efektif \\
\hline 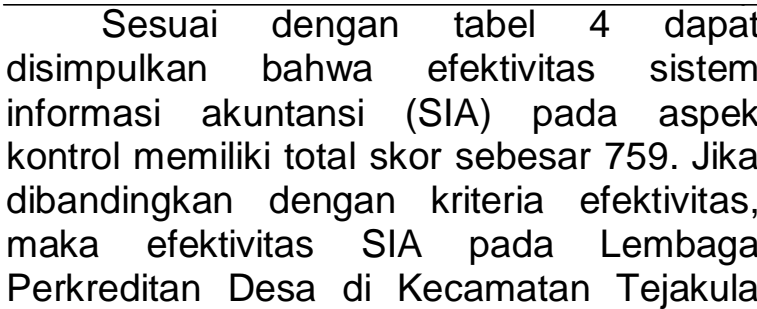 & & \multicolumn{2}{|c|}{$\begin{array}{l}\text { skor } 653 \leq \mathrm{KE}<806 \text { dengan Kriteria Efektif } \\
\text { (KE). } \\
\text { Efektivitas sistem informasi akuntansi } \\
\text { (SIA) pada Lembaga Perkreditan Desa di } \\
\text { Kecamatan Tejakula dinilai dari aspek } \\
\text { efisiensi dapat ditunjukkan seperti pada } \\
\text { tabel }\end{array}$} \\
\hline
\end{tabular}
pada aspek kontrol masuk dalam range

Tabel 5. Efektivitas Sistem Informasi Akuntansi (SIA) pada Aspek Efisiensi

\begin{tabular}{ccccc}
\hline & Indikator & Skor & Range Skor & $\begin{array}{c}\text { Kriteria } \\
\text { Efektivitas }\end{array}$ \\
\hline $\begin{array}{l}\text { Sistem harus memberdayakan sumber } \\
\text { daya yang tersedia termasuk orang, } \\
\text { waktu, aliran form }\end{array}$ & 493 & $435 \leq \mathrm{KE}<538$ & Kriteria Efektif \\
$\begin{array}{l}\text { Sistem dapat meminimalkan penundaan } \\
\text { proses }\end{array}$ & 502 & $435 \leq \mathrm{KE}<538$ & Kriteria Efektif \\
\hline $\begin{array}{c}\text { Total Skor } \\
\text { Aspek Efisiensi }\end{array}$ & 995 & $870 \leq \mathrm{KE}<1075$ & Kriteria Efektif \\
\hline $\begin{array}{l}\text { Sesuai dengan tabel 5 dapat } \\
\text { disimpulkan bahwa efektivitas sistem } \\
\text { informasi akuntansi (SIA) pada aspek }\end{array}$ & $\begin{array}{l}\text { efisiensi memiliki total skor sebesar 995. } \\
\text { Jika dibandingkan dengan kriteria } \\
\text { efektivitas, maka efektivitas SIA pada }\end{array}$ \\
\end{tabular}


Lembaga Perkreditan Desa di Kecamatan Tejakula pada aspek efisiensi masuk dalam range skor $870 \leq \mathrm{KE}<1075$ dengan Kriteria Efektif (KE).
Berdasarkan hasil analisis data menunjukkan bahwa efektivitas SIA pada Lembaga Perkreditan Desa di Kecamatan Tejakuladinilai dari aspek pelayanan dapat ditunjukkan seperti pada tabel 6 .

Tabel 6. Efektivitas Sistem Informasi Akuntansi (SIA) pada Aspek Pelayanan

\begin{tabular}{|c|c|c|}
\hline Indikator & Skor & $\begin{array}{c}\text { Kriteria } \\
\text { Efektivitas }\end{array}$ \\
\hline $\begin{array}{l}\text { Sistem menyediakan layanan yang } \\
\text { diinginkan dan andal }\end{array}$ & 494 & $435 \leq \mathrm{KE}<538$ \\
\hline $\begin{array}{l}\text { Sistem bersifat fleksibel dan dapat } \\
\text { dikembangkan }\end{array}$ & 249 & $217,6 \leq \mathrm{KE}<268,8$ \\
\hline $\begin{array}{c}\text { Total Skor } \\
\text { Aspek Pelayanan }\end{array}$ & 743 & $653 \leq \mathrm{KE}<806$ \\
\hline 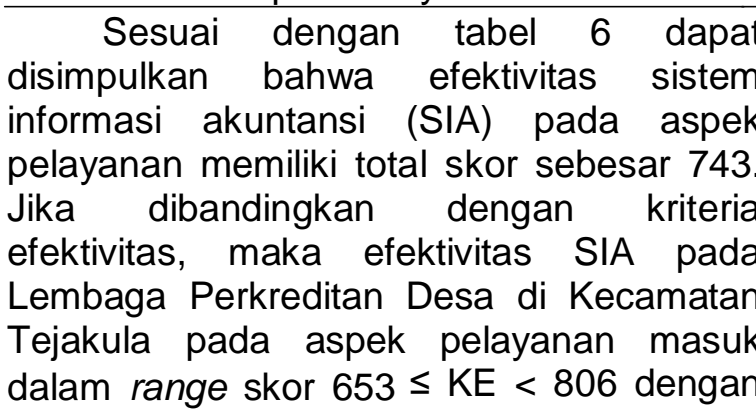 & & $\begin{array}{l}\text { Efektivitas sistem informasi akuntansi } \\
\text { (SIA) pada Lembaga Perkreditan Desa } \\
\text { secara total dapat dilihat dengan } \\
\text { menggabungkan seluruh aspek, yaitu } \\
\text { kinerja, informasi, ekonomis, kontrol, } \\
\text { efisiensi, dan pelayanan. Keseluruhan } \\
\text { penilaian efektivitas SIA pada Lembaga } \\
\text { Perkreditan Desa di Kecamatan Tejakula } \\
\text { tampak pada } 4 \text { tabel }\end{array}$ \\
\hline
\end{tabular}
Kriteria Efektif (KE).

Tabel 7. Efektivitas Sistem Informasi Akuntansi (SIA) Secara Total

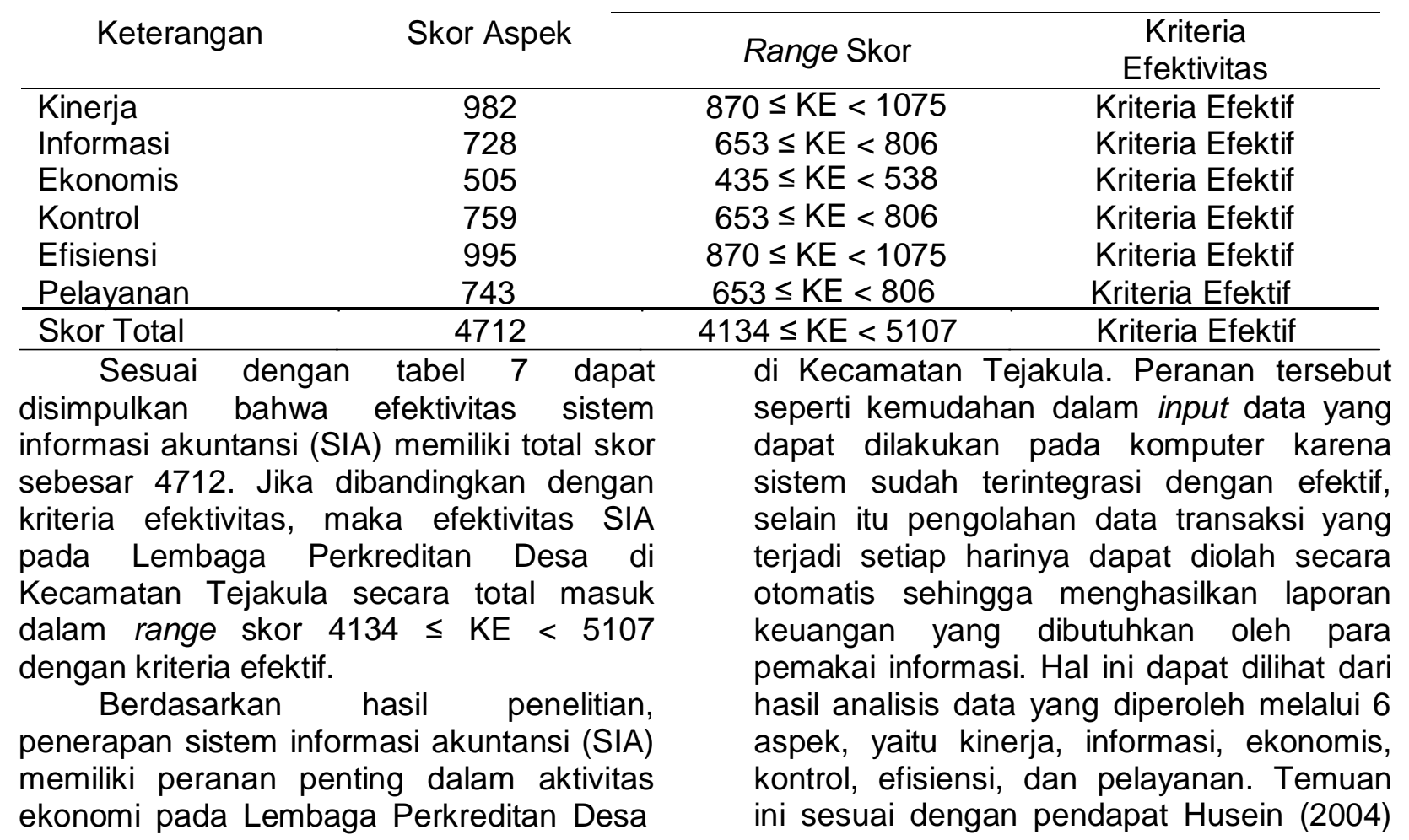


yang menyatakan bahwa untuk mengelola informasi secara efektif menjadi sumber daya yang bernilai, pengembangan sistem informasi akuntansi modern akan lebih baik jika menggunakan teknologi informasi dan jaringan komputer.

Lembaga Perkreditan Desa di Kecamatan Tejakula memiliki efektivitas sistem informasi akuntansi (SIA) pada aspek kinerja yang efektif. Hal tersebut dapat dilihat dari hasil analisis efektivitas pada aspek kinerja. Temuan ini membuktikan bahwa efektivitas SIA pada aspek kinerja mampu menyediakan data transaksi atau laporan keuangan dalam harian, mingguan, bulanan, dan tahunan serta memberikan data transaksi atau laporan keuangan pada setiap bagian jabatan/divisi yang ada di LPD. Sistem informasi akuntansi yang digunakan LPD dapat memberikan kecepatan respon dalam melakukan input data, pencarian data yang diperlukan, dan dalam melakukan proses analisis data. Sistem informasi akuntansi LPD juga cepat dalam merespon pelayanan terhadap nasabah termasuk penanganan keluhannya.

Hasil analisis efektivitas sistem informasi akuntansi (SIA) pada Lembaga Perkreditan Desa di Kecamatan Tejakula pada aspek informasi termasuk ke dalam kriteria efektif. Hal ini menunjukkan bahwa sistem informasi akuntansi yang digunakan LPD dapat menyediakan informasi transaksi keuangan dengan tepat waktu jika sewaktu-waktu diperlukan. Selain itu, sistem informasi akuntansi yang digunakan LPD dapat menyediakan keterkaitan setiap data transaksi keuangan dengan akurat. Sistem informasi akuntansi LPD juga dapat menyediakan informasi transaksi keuangan secara ringkas dan mudah dipahami oleh pengguna dan manajer. Hal ini memudahkan Lembaga Perkreditan Desa di Kecamatan Tejakula dalam mengolah data transaksinya. Temuan ini juga sesuai dengan pendapat Widjajanto (2001), yang menyatakan bahwa sistem dapat dikatakan efektif apabila sistem mampu menghasilkan informasi yang dapat diterima dan mampu memenuhi harapan informasi secara tepat waktu dan akurat.

Hasil analisis SIA pada Lembaga Perkreditan Desa di Kecamatan Tejakula pada aspek ekonomis termasuk ke dalam kriteria efektif. Hal ini menunjukkan bahwa sistem informasi akuntansi yang digunakan LPD memiliki kapasitas yang memadai dalam mencatat seluruh transaksi yang terjadi dan dapat mengurangi biaya dalam penyelenggaraan catatan akuntansi dalam formulir dan buku jurnal. Hal ini menunjukkan Lembaga Perkreditan Desa di Kecamatan Tejakula memiliki sistem yang memadai, praktis dan ekonomis.

Hasil analisis efektivitas sistem informasi akuntansi (SIA) pada Lembaga Perkreditan Desa di Kecamatan Tejakula pada aspek kontrol termasuk ke dalam kriteria efektif. Hal ini menunjukkan bahwa SIA yang digunakan LPD memiliki kontrol keamanan terhadap data yang disimpan di komputer dari akses karyawan maupun orang lain yang tidak berkepentingan, yaitu adanya password untuk setiap karyawan yang berkepentingan. Sistem informasi akuntansi yang digunakan LPD juga memiliki keamanan dalam input data jika ada yang tidak semestinya, maka pengguna (user) diperingatkan oleh komputer. Sistem informasi akuntansi LPD juga menjamin keamanan data yang disimpan di komputer dengan adanya backup sebagai cadangan atau pengganti. Hal ini menunjukkan Lembaga Perkreditan Desa di Kecamatan Tejakula memiliki sistem informasi akuntansi yang aman.

Hasil analisis efektivitas SIA pada Lembaga Perkreditan Desa di Kecamatan Tejakula pada aspek efisiensi termasuk ke dalam kriteria efektif. Hal ini menunjukkan bahwa sistem informasi akuntansi yang digunakan LPD memiliki dapat memberdayakan karyawan menjadi lebih berkualitas sehingga sistem dapat digunakan dengan efektif dan efisien serta memberdayakan aliran form transaksi keuangan lebih terstruktur dan akurat. Sistem informasi akuntansi LPD dapat melakukan proses pengolahan data dengan lebih cepat sehingga dapat meminimalkan penundaan proses. Hal ini menunjukkan Lembaga Perkreditan Desa di Kecamatan Tejakula memiliki sistem informasi akuntansi yang efektif dan efisien dalam memberdayakan karyawan dan transaksi keuangan yang terjadi. 
Hasil analisis efektivitas SIA pada Lembaga Perkreditan Desa di Kecamatan Tejakula pada aspek pelayanan termasuk ke dalam kriteria efektif. Hal ini menunjukkan bahwa sistem informasi akuntansi yang digunakan LPD memiliki memberikan pelayanan sesuai dengan kebutuhan perusahaan dan memberikan informasi transaksi atau laporan keuangan yang bebas dari kesalahan material, menyajikan setiap fakta secara jujur, serta dapat diverifikasi. Hal ini menunjukkan laporan keuangan yang dihasilkan Lembaga Perkreditan Desa di Kecamatan Tejakula menggunakan sistem informasi akuntansi dapat dipercaya karena bebas dari kesalahan material, menyajikan setiap fakta secara jujur, serta dapat diverifikasi. Temuan ini sesuai dengan pendapat Widjajanto (2001), yang menyatakan bahwa sistem dapat dikatakan efektif apabila sistem mampu menghasilkan informasi yang dapat diterima dan mampu memenuhi harapan informasi yang diperoleh dapat dipercaya (reliable).

\section{SIMPULAN DAN SARAN}

Berdasarkan hasil penelitian dan pembahasan, maka dapat ditarik simpulan bahwa efektivitas sistem informasi akuntansi (SIA) pada Lembaga Perkreditan Desa di Kecamatan Tejakula berada pada kriteria efektif. Hal ini dapat dilihat dari perolehan masing-masing aspek, yaitu aspek kinerja memiliki kriteria efektif sebesar 982, aspek informasi memiliki kriteria efektif sebesar 728 , aspek ekonomis memiliki kriteria efektif sebesar 505, aspek kontrol memiliki kriteria efektif sebesar 759, aspek efisiensi memiliki kriteria efektif sebesar 995, dan aspek pelayanan memiliki kriteria sangat efektif sebesar 743 .

Berdasarkan simpulan di atas, maka dapat diajukan dua saran sebagai berikut. Pertama bagi pihak pengelola Lembaga Perkreditan Desa di Kecamatan Tejakula, agar lebih memperhatikan aspek sistem informasi akuntansi kinerja, informasi, ekonomis, kontrol, efisiensi, dan pelayanan sebagai upaya untuk meningkatkan efektivitas SIA. Dengan demikian, pengelolaan LPD dapat meningkatkan kualitasnya dalam hal pengelolaan transaksi keuangan dan pelayanan terhadap nasabah. Kedua bagi peneliti selanjutnya yang tertarik untuk mengkaji aspek yang serupa mengenai efektivitas SIA diharapkan untuk mengembangkan penelitian ini dengan menggunakan populasi dan sampel yang lebih luas, tidak hanya LPD di Kecamatan Tejakula, tetapi juga di kecamatan lainnya agar hasil penelitian lebih teruji keandalannya.

\section{DAFTAR PUSTAKA}

Ayu, Santi, Ni Wayan. 2014. Efektivitas Penerapan Sia Berbasis Komputer Dengan Pendekatan Dbms Pada Ksp Sari Utama Mandiri. Jurnal Pendidikan Ekonomi Universitas Pendidikan Ganesha. 3(1), 7-18

Bastian, Indra. (2005) Akuntansi Sektor Publik. Jakarta: Penerbit Erlangga.

Bodnar, G. H. \& William, S. H. 2006. Sistem Informasi Akuntansi. Yogyakarta: Andi.

Husein Umar, 2004, Metode Penelitian Untuk Skripsi Dan Tesis Bisnis, Cet ke 6, Jakarta : PT Raja Grafindo Persada.

Jumaili, Salman. 2005. Kepercayaan Terhadap Teknologi Sistem Informasi Baru dalam Evaluasi Kinerja Individual. Makalah disajikan dalam Simposium Nasional Akuntansi VIII di Solo. 15-16 September 2005. 8, 722735

Kasmir. 2004. Bank \& Lembaga Keuangan Lainnya. Jakarta: PT. Raja Grafindo Persada.

Moeheriono. 2010. Pengukuran Kinerja Berbasis Kompetensi. Jakarta: Ghalia Indonesia.

Mulyadi. 2008. Sistem Akuntansi. Jakarta: Salemba. Empat.

Peraturan Gubernur Bali Nomor 11. 2013. Tentang Petunjuk Pelaksanaan Peraturan Daerah Provinsi Bali Nomor 8 Tahun 2002 Tentang Lembaga Perkreditan Desa Sebagaimana Telah Diubah Beberapa Kali Terakhir Dengan Peraturan Daerah Provinsi Bali Nomor 4 Tahun 2012 Tentang 
Perubahan Kedua Atas Peraturan Daerah Provinsi Bali Nomor 8 Tahun 2002 Tentang Lembaga Perkreditan Desa. Pemerintah Provinsi Bali.

Rahmawati, Diana. 2008. Analisis Faktor Faktor yang Berpengaruh Terhadap Pemanfaatan Teknologi Informasi. Jurnal Ekonomi dan Pendidikan, 5(1), 107-118.

Sari, Maria dan M. Ratna. 2009. Pengaruh Efektivitas Pemakaian dan Kepercayaan terhadap Teknologi Sistem Informasi Akuntansi terhadap Kinerja Individual pada Pasar Swalayan di Kota Denpasar. Jurnal IImiah Akuntansi dan Bisnis, 4(1) 1-20

Sugiyono. 2005. Metode Penelitian Administrasi. Bandung: Alfabeta.

-------. 2011. Metode Penelitian Kuntitatif, Kualitatif dan R\&D. Bandung: Alfabeta.

------. 2013. Metode Penelitian Bisnis. Bandung: Alfabeta.

Sukardi. 2003. Metodologi Penelitian Pendidikan Kompetensi dan Praktiknya. Jakarta: Bumi Aksara.

Supranto, J. 2001. Statistik Teori dan Aplikasi. Jakarta: Erlangga.

Widjajanto, Nugroho. 2001. Sistem Informasi Akuntansi. Jakarta : Erlangga. 